\title{
IMPLEMENTASI KEBIJAKAN KARTU TANDA PENDUDUK ELEKTRONIK
} (E-KTP)

\author{
Hisnindar, Abang Zainudin \\ Fakultas Ilmu Sosial dan Ilmu Politik Universitas Kapuas Sintang \\ Universitas Kapuas Sintang, Jl. Y.C. Oevang Oeray, No.92 Sintang Kalimantan Barat \\ Email:ab_jay57@yahoo.co.id
}

\begin{abstract}
Abstrak :Pemerintah Kecamatan dan Desa/Kelurahan memegang peranan yang sangat trategis dalam mensukseskan Implementasi Kebijakan Kartu Tanda Penduduk Elektronik (E-KTP). Dalam Implementasi Kebijakan E-KTP di Desa Jongkong Kiri Hilir Kecamatan Jongkong Kabupaten Kapuas Hulu dilakuakan melalui dua tahapan yaitu tahapan sosialisasi kebijakan dan pelaksanaan kebijakan. Sosilisasi kebijakan EKTP di Desa Jongkong Kiri Hilir dilakukan secara tidak terstruktur dan terjadwal yang dilaksakan oleh Pihak Dinas Catatan Sipil dan Kependudukan Kabupaten Kapuas Hulu, Pemerintah Kecamatan Jongkong dan Pemerintahan Desa Jongkong Kiri Hilir. Bentuk sosialisasi adalah secara lisan yang disampaikan dalam rapat atau pertemuan di Desa dan pemberitahuan di tempat ibadah. Dalam pelaksanaan kebijakan E-KTP Aparatur Desa Jongkong Kiri Hilir berpedoman pada peraturan perundang-undangan yang berlaku dan hanya sebatas memfasilitasi serta membuat surat pengantar bagi warga Desa yang akan melakukan proses perekaman dan pembuatan E-KTP di tingkat Kecamatan Jongkong. Terdapat faktor pendukung dan penghabat dalam Implementasi Kebijakan E-KTP di Desa Jongkong Kiri Hilir. Faktor pendukung, sumber daya manusia Apartur Desa yang sesuai dengan struktur organisasi dan sarana dan prasarana yang memadai dalam proses pengurusan E-KTP pada tingkat Desa. Sedangkan faktor penghambat adalah faktor geografis, dimana warga masyarakat yang terdapat di wilayah terpencil kesulitan dalam pengurusan E-KTP baik di tingkat desa maupun di tingkat Kecamatan.
\end{abstract}

Kata Kunci : Implementasi, Kebijakan, E-KTP

Fungsi Pemerintahan pada umumnya berupa penyediaan pelayanan umum, pengaturan dan perlindungan masyarakat serta pembangunan dan pengembangan.

Dalam rangka melaksanakan fungsinya dengan baik, struktur pemerintahan di Negara Kesaruan Republik Indonesia dibentuk mulai dari tingkat pusat sampai pada tingkat daerah. Karena negara dibentuk oleh masyarakat untuk memenuhi kebutuhan publik anggotanya, maka sesungguhnya pelayanan publik adalah kewajiban utama seluruh Perangkat pemerintah di setiap jenjang pemerintahan dan setiap jenis pelayanan publik. Salah satu pewujudan pelayanan publik adalah pelayanan Kartu Tanda Penduduk (KTP).

Sistem dan bentuk pelayanan KTP yang telah diterapkan di Indonesia dari era Orde Lama, Orde Baru sampai pada era Orde Reformasi, telah mengalami berbagai perubahan. Awalnya pelayanan KTP dilaksanakan secara manual kemudian berganti dengan sistem Elektronik. Kartu Tanda Penduduk adalah kebutuhan yang bersifat mutlak bagi setiap warga negara Indonesia dan orang asing yang memiliki ijin tinggal tetap yang telah berumur 17 tahun ke atas atau yang sudah menikah secara sah. Undang - Undang Nomor 23 Tahun 2006 tentang Administrasi Kependudukan pasal 13 ayat 1 mengamanatkan bahwa setiap penduduk wajib memiliki Nomor Induk Kependudukan (NIK). Berdasrkan amanat Undang - Undang Nomor 23 Tahun 2006 tersebut, Presiden Republik Indonesia mengeluarkan Instruksi Presiden Nomor 1 Tahun 2010 Tentang Prioritas Pertama Mengenai Reformasi Birokrasi dan Tata Kelola Pemerintahan, ditetapkan bahwa penertiban NIK dan pengembangan SIAK merupakan prioritas pembangunan Nasional.

Untuk mewujudkan tertib penyelenggaraan administrasi kependudukan dalam skala nasional dan menjamin kepastian hukum hak sipil penduduk, maka pemerintah dengan dukungan Dewan Perwakilan Rakyat Republik Indonesia telah memprogramkan tiga Program Strategis Nasional dibidang Kependudukan dan Pencatatan Sipil yang meliputi pemuktahiran data Kependudukan, Penerbitan Nomor Induk Kependudukan (NIK), penerapan KTP elektronik (E-KTP)

Sesuai dengan Surat Edaran Menteri Dalam Negeri Nomor 471.13/1565a/SJ. Tanggal 29 April 2011. Pemerintah Kecamatan dan Desa/Kelurahan memegang peranan yang sangat trategis dalam mensukseskan pelaksanaan Kartu Tanda Penduduk Elektronik. Dalam hal ini pemerintah kecamatan sebagai ujung tombak pelayanan, berdasarkan edaran tersebut dikatakan bahwa: Kantor Kecamatan sebagai pusat pelayanan E-KTP secara berkesimanbungan (on-line) ke database Kementerian Dalam Negeri. Membentuk Kelompok Kerja (Pokja) di tingkat kecamatan. Memberi Informasi /sosialiasasi berkaitan E-KTP kepada masyarakat pada setiap kesempatan kunjungan kerja. Menandatangani dan 
menyampaikan surat undangan kepada penduduk wajib KTP untuk melakukan perekaman data ditempat pelayanan E-KTP. Menugaskan 4 (empat) petugas operator untuk mengikuti bintek operator E-KTP ke Kabupaten yang diselenggarakan pihak konsorsium. Mengawasi setiap pendistribusian perangkat keras dan lunak oleh penyedia (konsorsium) ke Kecamatan. Menyediakan Jabwal pelayanan ke desa-desa yang jauh dan melayani dengan pola jemput bola terhadap warga yang tidak datang karena jompo, cacat fisik, sakit keras tempat tinggal jauh dan sebagainya dengan membawa perangkat aplikasi mobil enrolment (Jika tersedia). Menyediakan dan menyiapkan tempat pelayanan E-KTP seperti: Ruang pelayanan, Ruang/Gudang penyimpanan E-KTP, Perlengkapan Kantor untuk pelayanan, Meningkatkan Catu Daya listrik/ Pengadaan genset bagi yang tidak memiliki listrik, Menyiapkan tenda dan kursi untuk ruang tunggu penduduk. Mengoptimalkan peranan Pemerintahan Desa dan Kelurahan dalam rangka sosialisasi dan mobilisasi masyarakat wajib KTP ke tempat pelayanan. Melakukan koordinasi dan konsultasi ke Dinas Kenpendudukan dan pencatatan Sipil.

Desa Jongkong Kiri Hilir adalah merupakan salah satu Desa yang terdapat di Kecamatan Jongkong Kabupaten Kapuas Hulu. Dalam pembuatan Kartu Tanda Pendudukan dengan sistem elektronik di pemerintah Kecamatan Jongkong, Pemerintahan Desa Jongkong Kiri Hilir turut serta dalam proses pembuatan E-KTP di Kecamatan Jongkong. Kontribusi Desa Jongkong Kiri Hilir dalam proses pembuatan E-KTP berhubungan penyediaan dan validasi data kependudukan secara lengkap, memfasilitasi proses administrasi dan pelaporan data penduduk. Dalam proses pembuatan E-KTP belum dapat dilaksanakan secara maksimal, dimana berdasarkan data kependudukan, jumlah penduduk Desa Jongkong Kiri Hilir sampai dengan tahun 2017 berjumlah 881 jiwa yang terdiri dari 455 jiwa berjenis kelamin laki-laki dan 426 jiwa berjenis kelamin perempuan. Dari Jumlah penduduk 881 jiwa tersebut yang wajib memiliki Kartu Tanda Penduduk Elektronik seharusnya berjumlah 724 orang, namun yang dalam kenyatannya penduduk yang sudah memiliki E-KTP baru berjumlah 677 orang, sehingga masih terdapat penduduk yang belum memiliki E-KTP berjumlah 47 orang. Kenyataan lainnya juga terjadi pada pembuatan Kartu Keluarga (KK), dimana berdasrkan data yang terdapat di Kantor Kepala Desa Desa Jongkong Kiri Hilir, penduduk yang wajib memiliki KK seharusnya berjumlah 293 orang, namun dalam kenyataannya, penduduk yang sudah memiliki KK baru berjumlah 279 orang, sehingga masih terdapat penduduk yang belum memiliki KK sebanyak 14 orang.

Sosialisasi kebijakan Kartu Tanda Penduduk Elektronik (E-KTP) pada dasarnya merupakan proses komunikasi guna memberikan informasi tentang E-KTP sehingga dapat memberikan pemahaman bagi masyarakat secara baik dan benar. Dalam kaitan tersebut, keberadaan komunikasi juga merupakan aspek penting dalam proses implementasi kebijakan. Komunikasi sebagai proses penyampaian informasi dengan mengunakan lambang yang mempunyai arti diantara dua orang atau lebih. Sejalan dengan itu Edwards III (Tangkilisan, 2003 : 19) "ada tiga aspek komunikasi dalam implementasi kebijakan, yaitu transmisi, kejelasan dan konsistensi". Transmisi berkaitan dengan pemberian atau penyebaran informasi yang berkenaan dengan kebijakan publik itu sendiri. Sedangkan kejelasan berhubungan dengan sejauhmana proses transmisi terjadi secara akurat. Sementara konsistensi adalah sejauhmana informasi yang ditransmisi/disampaikan tidak berubah-ubah atau tetap konsisten.

Dalam hal struktur, komunikasi mengacu pada rumus yang ditawarkan oleh Lasswell (dalam Effendy, 1992 : 29) bahwa "komunikasi memiliki 5 (lima) komponen yaitu komunikator, pesan, media, komunikan dan efek".Dimensi komunikasi ini dapat terjadi antara birokrasi selaku aparat pelaksana dengan masyarakat sebagai target group kebijakan atau internal birokrasi itu sendiri. Komunikasi antara birokrasi dengan masyarakat berupa terjadinya kontak tatap muka secara langsung berupa dialog (saling bertukar pemikiran) yang bentuknya dapat berupa kegiatan sosialisasi dan pembinaan dari aparat birokrasi kepada masyarakat. Sosialisasi berkenaan dengan proses penyebaran informasi tentang keberadaan program kebijakan yang akan dilakukan sehingga lahir pemahaman yang benar bagi target group. Sedangkan pembinaan merupakan kegiatan yang diarahkan untuk membentuk sikap dan perilaku target group yang sesuai tujuan kebijakan. Dilain pihak, komunikasi internal birokrasi berupa proses pemberian perintah dan petunjuk dari atasan kepada bawahan guna memperlancar operasionalisasi kegiatan dari kebijakan tersebut.

Pemerintah menerapkan E-KTP merupakan bagian dari program pemerintah yang dikenal sebagai E-Government. Program EGovernment yang diterapakan oleh pemerintah bertujuan untuk mewujudkan pemerintahan yang demokratis, transparan, bersih, adil, akuntabel, bertanggungjawab, responsive, efektif dan efisien. Seperti yang tercantum dalam Undang-Undang Nomor 11 Tahun 2008 Tentang Informasi Dan Transaksi Elektronik. E-Government menerapkan sistem pemerintahan dengan berbasis elektronik agar dapat memberikan kenyamanan, meningkatkan transparansi, dan meningkatkan interaksi dengan masyarakat, serta meningkatkan partisipasi publik. Penerapan KTP Elektronik merupakan amanat dari Undang-Undang Nomor 23 Tahun 2006 Tentang Administrasi Kependudukan. E-KTP sangat perlu untuk dapat menciptakan sistem administrasi kependudukan yang rapi dan teratur dalam rangka 
mempermudah pemberian pelayanan publik oleh pemerintah kepada seluruh masyarakat. Program E-KTP dapat dilaksanakan secara efektif apabila program tersebut didukung oleh seluruh elemen masyarakat. Dukungan masyarakat sangat tergantung pada pemehaman mereka akan arti penting E-KTP tersebut, oleh karena itulah kegiatan sosialisasi E-KTP sangat perlu dilakukan oleh Pemerintah.

Sosialisasi diartikan sebagai sebuah proses seumur hidup bagaimana seorang individu mempelajari kebiasaan-kebiasaan yang meliputi cara-cara hidup, nilai-nilai, dan norma-norma social yang terdapat dalam masyarakat agar dapat diterima oleh masyarakatnya. Menurut Soekamto (2009:217). Sosialisasi adalah "proses mengkomunikasikan kebudayaan kepada warga masyarakat yang baru". Dari pengertian yang dikemukakan tersebut dapat disimpulkan bahwa sosialisasi merupakan suatu proses belajar seorang anggota masyarakat untuk mengenal dan menghayati norma-norma serta nilai-nilai masyarakat tempat ia menjadi anggota, sehingga terjadi pembentukan sikap untuk berperilaku sesuai dengan tuntutan atau perilaku masyarakatnya. Jadi, proses sosialisasi membuat seseorang menjadi tahu dan memahami bagaimana harus bersikap dan bertingkah laku di lingkungan masyarakatnya. Secara sederhana sosialisasi dapat dipahami sebagai proses memperkenalkan kembali berbagai konsep dan tatanan baru yang akan dilaksanakan oleh pihak pemerintah berdasarkan kepentingan masyarakat. sehubungan dengan kebijakan pemerintah tentang kependudukan yaitu dengan dikeluarkannya Peraturan Presiden Republik Indonesia Nomor 67 Tahun 2011 Tentang Perubahan Kedua Atas Peraturan Presiden Nomor 26 Tahun 2009 Tentang Penerapan Kartu Tanda Penduduk Berbasis Nomor Induk Kependudukan Secara Nasional.

Kegiatan sosialisasi program sangat mempengaruhi pelaksanaan program. Sosialisasi tidak hanya sekedar pemberitahuan serta penyuluhan tetapi diharapkan sasaran memiliki kesadaran untuk mengikuti program yang ada. Selain itu peran sosialisasi juga menentukan tingkat utilitas. Sosialisasi yang tidak maksimal dapat menyebabkan tingkat kedatangan dan penggunaan pelayanan tidak bertambah yang akan berdampak pada tingkat kelayakan pengadaan program itu sendiri. Dengan tingkat utilitas rendah tentu sistem tidak berjalan dengan maksimal dan akan menimbulkan kerugian baik biaya, waktu maupun tenaga.

Sosialiasi tentang pergantian identitas kependudukan yang berbentuk elektronik sudah sejak lama dilakukan oleh pemerintah melalui media massa. Tujuan dari sosialiasi sendiri yaitu menggerakan seluruh komponen dalam masyarakat agar mempersiapkan berbagai persyaratannya. Pelayanan terhadap masyarakat dalam mempersiapkan berbagai persyaratan sebagaimana yang tertuang dalam peraturan diatas yaitu melibatkan berbagai sumber untuk dapat membantu terselenggaranya kebijakan secara efektif.Sosialisasi program terhadap pemerintah yang berkaitan dengan masyarakat adalah suatu yang mutlak dilakukan didalam melaksanakan sebagai program kerja pemerintah pada tingkat masyarakat.

Melaksanakan amanat Undang-Undang Nomor 23 Tahun 2006 Tentang Administrasi Kependudukan, merupakan perwujudkan tertib Penyelenggaraan administrasi kependudukan dalam skala nasional dan menjamin kepastian hukum hak sipil penduduk. Melalui akurasi data kependudukan yang berbasis pada Nomor Induk Kependudukan (NIK), maka dapat diterbitkan Kartu Tanda Penduduk Elektronik (E-KTP) yang berlaku secara nasional, sehingga tidak diperlukan lagi KTP daerah/ lokal sebagai persyaratan pelayanan publik. Disamping itu KTP Elektronik juga mampu memberi rasa aman kepada masyarakat karena tidak dapat dipalsukan.

Implementasi Kebijakan merupakan suatu tindakan (action) atau intervensi yang dilakukan pemerintah maupun swasta agar program kebijakan dapat mencapai tujuan. Sebelum kebijakankebijakan publik diimplementasikan terlebih dahulu dikaji secara mendalam tentang bagaimana organisasi pelaksana program atau birokrasi, dalam menerima prosedur atau mekanisme implementasi kebijakan pemerintah tersebut.Implementasi kebijakan pemerintah bersangkut paut dengan ikhtiar-ikhtiar untuk mencapai tujuan tertentu. Implementasi kebijakan pemerintah merupakan penjabaran lebih lanjut dari pada tujuan yang telah ditetapkan tersebut oleh pejabat atau instansi pelaksana.

Implementasi kebijakan merupakan aspek penting dari keseluruhan proses kebijakan, karena apabila suatu kebijakan tidak diimplementasikan, maka akan menjadi sekedar impian belaka. Pelaksanaan atau implementasi kebijakan menurut Jones (1996 : 51) berkaitan dengan pertanyaan sebagai berikut: "siapa yang menjalankan dan bagaimana mereka memelihara dukungan yang didapatkan". Selanjutnya Dunn (1998 : 24), dalam fase implementasi kebijakan mengandung karakteristik bahwa "kebijakan yang telah diambil dilaksanakan oleh unit-unit administrasi yang memobilisasikan sumber daya finansial dan manusia".

Salah satu ukuran tercapainya tujuan suatu kebijakan adalah pada teknis operasionalnya atau bagaimana implementasinya di lapangan sebagaimana yang dikemukakan Parker (dalam Sunggono, 1994 : 137) bahwa : "implementasi kebijakan merupakan suatu upaya untuk mencapai tujuan-tujuan tertentu dengan sarana-sarana tertentu dan dalam urutan waktu tertentu. Dengan 
demikian, yang diperlukan dalam implementasi kebijakan itu adalah tindakan-tindakan seperti tindakan-tindakan yang sah atau implementasi suatu rencana peruntukkan. Implementasi kebijakan negara merupakan rangkaian proses dari suatu kebijakan. Oleh karena itu implementasi kebijakan negara perlu dilaksanakan dengan sebaik mungkin menurut Winarno, (2002:101) karena "implementasi kebijakan merupakan tahap yang krusial dalam proses kebijakan publik." Sejalan dengan hal tersebut, model implementasi kebijakan negara menurut Sabatier dan Mazman (dalam Wibawa, 1992:31) menyatakan "ada dua model implementasi kebijakan, model pertama adalah Top Down dan model kedua adalah Bottom Up. Suatu program kebijakan harus diimplementasikan agar dapat dilihat hasil riil dari kebijakan tersebut.

Selanjutnya Winarno (2002:102) mengatakan implementasi kebijakan adalah : Merupakan alat administrasi hukum dimana berbagai aktor, organisasi, prosedur dan teknik yang bekerja bersama-sama untuk menjalankan kebijakan guna meraih tujuan yang diinginkan. Implementasi pada sisi yang lain merupakan fenomena yang kompleks yang mungkin dapat dipahami sebagai proses, keluaran (output) maupun sebagai hasil. Sementara menurut Wibawa (1992:15) tujuan implementasi kebijakan adalah "untuk menetapkan arah agar tujuan-tujuan kebijakan publik dapat direalisasikan sebagai hasil dari kegiatan pemerintah". Oleh karena itu dalam implementasi kebijakan perlu diciptakan sistem pelaksanaan kebijakan sedemikian rupa agar implementasi kebijakan tersebut dapat terlaksana dengan baik. Untuk itu implementasi kebijakan perlu diterjemahkan kedalam program-program yang nyata.

Dalam proses implementasi kebijakan, terdapat faktor-faktor yang mempengaruhi anggota dalam satu kelompok (organisasi) untuk melaksanakan ataupun tidak melaksanakan sebuah kebijakan. Faktor yang mempengaruhi anggota organisasi ataupun suatu kelompok untuk melaksanakan kebijakan dapat dikategorikan sebagai faktor pendukung dari implementasi kebijakan. Sejalan dengan hal tersebut Sunggono (1994: 144) menyatakan bahwa:faktor-faktor yang menyebabkan masyarakat melaksanakan kebijakan publik:Respek anggota terhadap otoritas dan keputusan-keputusan baban pemerintah; Adanya kesadaran untuk menerima kebijakan;Adanya keyakinan bahwa kebijakan itu dibuat secara sah;Konstitusional dan dibuat oleh pejabat pemerintah yang berwenang untuk ikut serta;Adanya kepentingan pribadi;Adanya hukuman-hukuman tertentu bila tidak melaksanakan kebijakanMasalah waktu

Dengan demikian dapat dikatakan bahwa suatu kebijakan publik akan dapat dilaksanakan secara efektif apabila kebijakan publik tersebut didukung oleh beberapa faktor-faktor yang mempengaruhinya. Faktor yang pendukung sutu kebijakan publik dapat dilaksanakan secara efektif dapat bersumber dari faktor isi kebijakan, faktor pelaksana kebijakan dan faktor sasaran kebijakan. Ketiga faktor tersebut merupakan faktor yang menentukan berhasil tidaknya implementasi suatu kebijakan publik. Faktor pendukung berhasil tidaknya implementasi kebijakan publik adalah ketersediaan sarana dan prasarana. Menurut Manullang (1983:5), "sarana dan prasarana merupakan alat manajemen yang digunakan dalam organisasi untuk pencapaian tujuan, yang meliputi Men, Money, Material, Machines, Methode dan Markets." Dengan demikian fasilitas fisik dalam bentuk sarana dan prasarana merupakan sumbersumber penting dalam pelaksanaan pekerjaan. Menurut Edward (dalam Winarno, 2005 : 137) bahwa: "seorang pelaksana mungkin mempunyai staf yang memadai, mungkin memahami apa yang harus dilakukan, dan mungkin memahami wewenang untuk melakukan tugasnya, tetapi tanpa bangunan seperti kantor untuk melakukan koordinasi, tanpa perlengkapan, tanpa perbekalan, maka besar kemungkinan pelayanan publik yang direncanakan tidak akan berhasil.

Demikian halnya dalam Implementasi Kebijakan Kartu Tanda Penduduk Elektronik (EKTP) Kabupaten Kapuas Hulu, fasilitas-fasilitas tersebut merupakan faktor yang sangat mempengaruhi dalam proses pembuatan E-KTP. Fasilitas-fasilitas ini biasanya kita sering menyebutnya sebagai sarana dan prasarana. Sarana dan prasarana yang diperlukan proses pembuatan E-KTP adalah gedung yaitu suatu bangunan yang dikonstruksi sedemikian rupa sehingga seluruh kegiatan dapat dilaksanakan dengan aman, tertib, dan menyenangkan sehingga dapat dicapai kinerja maksimal; peralatan yaitu suatu perangkat yang diperlukan oleh personil yang melakukan kegiatan di mana tanpa peralatan tersebut tidak mungkin dicapai hasil yang baik dan memenuhi persyaratan yang telah ditentukan; mesinyaitu suatu perangkat yang berfungsi di samping sebagai sarana bantu untuk membuat suatu produk juga berperan sebagai pemercepat proses kerja; dan Perabot ruangan yaitu merupakan perlengkapan yang diletakkan dalam suatu ruangan, sehingga kegiatan dapat dilaksanakan dengan lancar, efektif dan efisien.

Setiap tugas pekerjaan pokok untuk mencapai tujuan tertentu harus didukung oleh pelayanan perkantoran. Pelayanan perkantoran terdiri dari segenap pekerjaan perkantoran yang dilaksanakan untuk mendukung tercapainya tujuan organisasi. Selain meja kursi, maka perabotan kantor yang umum dipakai di perkantoran adalah lemari (lemari warkat, lemari rak dan lemari brandkas), dan peralatan kantor seperti pesawat telepon,komputer, , televisi, papan tulis, papan 
pengumuman dan lain sebagainya. Adapun fungsi peralatan kantor menurut Gie (2005:256) adalah : "a). mempertinggi kemampuan pegawai yang mempergunakan alat-alat tersebut, b). memperkecil pengorbanan waktu, tenaga dan biaya, c). mempertinggi kualitas dan kuantitas hasil kerja dan d). mempertinggi kelangsungan kesejahteraan kerja."

Selain ketersediaan sarana dan prasarana, keberhasilan implementasi kebijakan publik juga ditentukan oleh dukungan anggaran. Berbagai definisi anggaran telah dikemukakan oleh para ahli, dan diantaranya adalah pengertian anggaran menurut Supriyono (1994:90) adalah : "suatu rencana terinci yang yang dinyatakan secara formal dalam satuan kuantitatif, biasanya dalam satuan uang untuk menunjukkan perolehan dan penggunaan sumber-sumber suatu organisasi dalam jangka waktu tertentu." Tunggal (1996:6) mendefinisikan anggaran adalah : "rencana manajemen (management plan) dengan maksud bahwa langkah-langkah positif harus dilakukan untuk membuat apa yang akan dipakai (realisasi/ aktual) sesuai dengan yang direncanakan." Menurut Adisaputro dan Asri (1984:6) : "anggaran adalah suatu pendekatan yang formal dan sistematis dari pada pelaksanaan tanggungjawab manajemen di dalam perencanaan koordinasi dan pengawasan".

Lebih lanjut Gomes (1995:85) mengatakan: "anggaran merupakan pusat pertemuan antara politik dengan administrasi publik, dan merupakan proses lewat mana konflik-konflik nilai di atasi dan diterjemahkan kedalam programprogram kongkret melalui pengalokasian sumbersumber daya yang langka ketujuan-tujuan program". Sedangkan menurut Blocher et.al. yang dialihbahasakan oleh Ambarriani (2000:350) mengemukakan bahwa : "anggaran merupakan rencana kuantitatif terhadap operasi organisasi, anggaran mengidentifikasi sumber daya dan komitmen." Menurut Anthony dan Govindarajan (1998:360), bahwa anggaran adalah suatu alat perencanaan dan pengendalian yang efektif di dalam organisasi, yang bersifat jangka pendek biasanya mencakup periode satu tahun.

Anggaran Pendapatan dan Belanja Negara (APBN) dan Anggaran Pendapatan dan Belanja Daerah (ABPD) merupakan perkiraan pendapatan dan belanja yang diharapkan akan terjadi dalam jangka waktu tertentu, dinyatakan dalam satuan mata uang dan ditetapkan dengan Undang-undang Republik Indonesia Nomor 17 Tahun 2003. Pasal 1 ayat $(7,8)$ tentang Keuangan Negara menyebutkan: Anggaran Pendapatan dan Belanja Negara, selanjutnya disebut APBN, adalah rencana keuangan tahunan pemerintahan negara yang disetujui oleh Dewan Perwakilan Rakyat. Anggaran Pendapatan dan Belanja Daerah, selanjutnya disebut APBD, adalah rencana keuangan tahunan pemerintahan daerah yang disetujui oleh Dewan Perwakilan Rakyat Daerah.
APBN menempatkan anggarannya untuk belanja semua sektor Pembangunan dari Pusat sampai ke daerah, sedangkan APBD menempatkan sebagian kegiatan rutin yang dibiayai oleh belanja pembangunan untuk daerah. Dalam hal itu dapat dibandingkan antara mata anggaran dalam satu kelompok atau antara belanja rutin dengan pembangunan, dimana anggaran pembangunan itu dibelanjakan dalam berbagai sektor yang menyangkut sektor ekonomi, politik, hukum dan kebijakan keuangan lainnya. Menurut Indra (2001: 42)Aspek-aspek anggaran mencakup antara lain :Aspek Ekonomi adalah Besaran anggaran pemerintah mencerminkan skala kegiatan ekonomi sektor pemerintahan dan pengaruhnya terhadap ekonomi swasta, Aspek Politik Anggaran adalah merupakan perwujudan dari kehendak politik yang sedang berkuasa kedalam kebijakan keuangan, Aspek Hukum adalah Agar dapat dilaksanakan, anggaran perlu ditetapkan dengan Undang-Undang, Anggaran mempunyai kekuatan hukum yang mengikat dan harus dipatuhi oleh semua pihak yang melaksanakan dan Aspek Manajemen adalah Anggaran mencerminkan pelaksanaan fungsifunsgsi manajemen pemerintah.Anggaran merupakan pedoman pelaksanaan kerja dan berfungsi sebagai alat untuk mengevaluasi kinerja yang telah dicapai suatu institusi. Anggaran juga dapat digunakan sebagai alat untuk mengembangkan ke arah yang lebih baik, dengan kata lain anggaran dapat meningkatkan efektivitas organisasi atau institusi dalam mencapai tujuannya.Oleh karena itu, peyusunan anggaran yang baik akan memberikan manfaat yang positif bagi organisasi atau institusi.Dalam kaitannya dengan penelitian ini, maka anggaran juga menjadi hal yang sangat urgen dalam meningkatkan efektivitas pelayanan pembuatan E-KTP.

Faktor pendukung lainnya dalam implementasi kebijakan publik adalah Sumber Daya Manusia. Sumber Daya Manusia (SDM) adalah faktor sentral dalam suatu organisasi. Apapun bentuk serta tujuannya, organisasi dibuat berdasarkan berbagai visi untuk kepentingan manusia dan dalam pelaksanaan misinya dikelola dan diurus oleh manusia. Jadi, manusia merupakan faktor strategis dalam semua kegiatan institusi/organisasi. Sedangkan sumber daya manusia adalah kemampuan terpadu dari daya pikir dan daya fisik yang dimiliki individu, perilaku dan sifatnya ditentukan oleh keturunan dan lingkungannya, sedangkan prestasi kerjanya dimotivasi oleh keinginan untuk memenuhi kepuasannya. Sikula (dalam Yudhi:2008) mengemukakan bahwa: "Perencanaan sumber daya manusia atau perencanaan tenaga kerja didefinisikan sebagai proses menentukan kebutuhan tenaga kerja dan berarti mempertemukan kebutuhan tersebut agar pelaksanaannya berinteraksi dengan rencana organisasi”. Sedangkan menurut Siagian (2000:41) 
mengatakan bahwa: Apabila berbicara tentang perencanaan sumber daya manusia, yang menjadi fokus perhatian ialah langkah-langkah tertentu yang diambil oleh manajemen guna lebih menjamin bahwa bagi organisasi tersedia tenaga kerja yang tepat untuk menduduki berbagai kedudukan, jabatan dan pekerjaan yang tepat pada waktu yang tepat.

Menurut Sunggono (1994: 144) menyatakan faktor penghambat dari implementasi kebijakan adalah sebagai berikut: Faktor-faktor yang menyebabkan anggota tidak melaksanakan kebijakan: 1).Kebijaksanaan yang bertentangan dengan sistem nilai; 2).Adanya konsep ketidak patuhan selektif terhadap hukum; 3).Keanggotaan seseorang dalam suatu perkumpulan atau kelompok; 4).Keinginan untuk mencari untung cepat; 5).Adanya ketidak patuhan Hukum".

Dari berbagai faktor tersebut, maka jelas sekali bahwa terdapat banyak faktor yang turut mempengaruhi dalam implementasi kebijakan publik. Hal ini akan berkaitan pula dengan efektifnya suatu kebijakan. Sebagaimana dikemukakan oleh Islamy (2000 : 107) bahwa;Suatu kebijakan Negara akan menjadi efektif apabila dilaksanakan dan mempunyai dampak positif bagi anggota-anggota masyarakat. Dengan kata lain, tindakan atau perbuatan manusia yang menjadi anggota masyarakat itu bersesuaian dengan apa yang diinginkan oleh Pemerintah atau Negara. Dengan demikian kalau mereka tidak bertindak/ berbuat sesuai dengan keinginan Pemerintah/ Negara itu, maka kebijaksanaan Negara menjadi tidak efektif.

\section{METODE}

Dalam penelitian ini, jenis penelitian yang dipilih adalah non-eksperimental (tidak dengan melakukan percobaan) yaitu penelitian deskriptif dengan pendekatan kualitatif. Menurut pandangan Suryabrata (2005:97) bahwa: "penelitian deskriptif bertujuan membuat pencandraan (deskripsi) secara sistematis, faktual dan akurat mengenai fakta-fakta dan sifat-sifat populasi atau daerah tertentu." Selanjutnyamenurut Narbuko dan Achmadi (1997:44) bahwa: Penelitian deskriptif yaitu penelitian yang berusaha untuk menuturkan pemecahan masalah yang ada sekarang berdasarkan data-data, jadi ia juga menyajikan data, menganalisis data dan menginterprestasi. Adapun tujuan penelitian deskriptif adalah untuk pemecahan masalah secara sistematis dan faktual mengenai fakta-fakta dan sifat-sifat populasi.

Peneliti menggunakan metode deskriptif sebagai prosedur atau cara yang ditempuh dalam memecahkan masalah yang dihadapi. Dimana Peneliti ingin mendiskripsikan tentang Implementasi Kebijakan Kartu Tanda Penduduk Elektronik (EKTP) Di Desa Jongkong Kiri Hilir Kecamatan Jongkong Kabupaten Kapuas Hulu. Untuk mendapatkan data yang diperlukan langkah-langkah penelitian yang akan dilakukan penulis sebagai berikut: (1).Studi kepustakaan yaitu mencari data - data melalui perpustakaan dengan membaca buku yang ada hubungan dengan tulisan, sehingga nantinya dapat menemukan dan mengemukakan pendapat dari masing - masing pakar untuk menjadi konsep dasar bagi penyusunan masalah yang akan diteliti; (2).Penelitian lapangan yaitu penelitian ini dilakukan dimana para subjek penelitian dapat dijelaskan yang mengayngkut penelitian tentang Implementasi Kebijakan Kartu Tanda Penduduk Elektronik (E-KTP) Di Desa Jongkong Kiri Hilir Kecamatan Jongkong Kabupaten Kapuas Hulu. Penelitian studi dilapangan ini dilakukan dalam rangka pengumpulan data primer atau data pokok yang bersumber dari informasi dan data sekunder yaitu data yang telah tersedia sebelum penelitian ini dilaksanakan.

Subjek penelitian atau sumber informasi dalam penelitian ini, yang menjadi subjek berjumlah 4 (empat) orang yang terdiri dari : Kepala Desa Jongkong Kiri Hilir, Ketua BPD Desa Jongkong Kiri Hilir, 2 (dua) orang Kepala Seksi (KASI) Desa Jongkong Kiri Hilir. Subjek dalam penelitian ini dipilih dengan pertimbangan yang bersangkutan memahami dan berkaitan dengan Implementasi Kebijakan Kartu Tanda Penduduk Elektronik (EKTP) Di Desa Jongkong Kiri Hilir. Dengan adanya penetapan subjek penelitian yang jelas maka diharapkan hasil penelitian ini akan lebih valid.

Teknik Pengumpulan data yang peneliti lakukan adalah:1). wawancara atau interview,2).Observasi atau pengamatan yang dilakukan oleh peneliti terhadap berbagai objek yang sesuai dengan fokus atau aspek penelitian; dan 3). Studi Dokumentasi.Metode analisis data yang digunakan adalah analisis non statistik, dimana pertama-tama data itu diseleksi atas dasar reabilitas dan validitasnya. Data yang telah lulus seleksi itu lalu diatur dalam tabel atau matriks agar memudahkan pengolahan selanjutnya.Sedangakan tahapan analisis data dilakukan 4 (empat) tahapan yaitu : 1).Tahap Persiapan, yaitu mengumpulkan data yang telah diolah, menyangkut kegiatan koordinasi, perencanaan dan faktor mempengaruhinya; 2). Tahap Penilaian Data, yaitu validitas, obyektivitas dan relibilitasi data dengan cara mengkatagorikan data dengan sistem pencatatan dan perbandingan;3). Tahap Interpretasi Data, yaitu memberikan interpretasi atau penafsiran terhadap data-data yang telah diseleksi untuk kemudian diuraikan atau dijabarkan dalam bentuk pertanyaan atau pun argumentasi;4). Tahap Penyimpulan, yaitu Tahap kesimpulan, yaitu merupakan tahap akhir dari analisis data, dimana peneliti memberikan keputusan akhir dari hasil penafsiran sesuai dengan fokus atau ruanglingkup yang diteliti. 


\section{HASIL PENELITIAN DAN PEMBAHASAN}

Desa Jongkong Kiri Hilir merupakan salah satu Desa yang terdapat di Kecamatan Jongkong Kabupaten Kapuas Hulu yang luas wilayahnya $91,87 \mathrm{KM}^{2}$ atau 9.187 Ha. Desa Jongkong Kiri Hilir secara geografis letaknya cukup starategis, dimana posisi Desa Jongkong Kiri Hilir merupakan salah satu desa yang berada di wilayah ibu kota Kecamatan Jongkong Kabupaten Kapuas Hulu. Secara administratif, batas wilayah Desa Jongkong Kiri Hilir adalah sebagai berikut : Sebelah Utara ,berbatasan dengan Desa Lemboyan dan Desa Semalah Kecamatan Selimbau Kabupaten Kapuas Hulu; Sebelah Selatan , berbatasan dengan Desa Jongkong Pasar Kecamatan Jongkong Kabupaten Kapuas Hulu;Sebelah Timur, b e r b a t a s a n dengan Desa Jongkong Kiri Tengah dan Desa Jongkong Kiri Hulu Kecamatan Jongkong Kabupaten Kapuas Hulu; Sebelah Barat, berbatasan dengan Desa Piasak Hulu dan Desa Yega Kecamatan Selimbau Kabupaten Kapuas Hulu.

Jumlah penduduk Desa Jongkong Kiri Hilir pada tahun 2018 berjumlah 881 jiwa yang terdiri dari laki-laki berjumlah 455jiwa dan perempuan berjumlah 426 jiwa.Penduduk Desa Jongkong Kiri Hilir rata-rata hidup sebagai pekerja, mulai dari umur 17 tahun sampai dengan usia 69 tahun, dari usia kerja penduduk Desa Jongkong Kiri Hilir yang ada, sebagian besar berusia pada kisaran usia 1769 tahun yang berjumlah 772 jiwa. Penduduk Desa Jongkong Kiri Hilir sudah dapat mengenyam pendidikan formal mulai dari tingkatan Sekolah Dasar sampai dengan tingkatan Perguruan Tinggi. Sebagian besar penduduk Desa Jongkong Kiri Hilir sudah mengenyam pendidikan formal. Dari pendidikan formal penduduk Desa Jongkong Kiri Hilir, jumlah yang terbesar adalah tamatan Sekolah Menengah Atas yang mencapai 40,98 \% yangkemudian diikuti tamatan Sekolah Menengah Pertama 26,56 \% dan tamatan Sekolah Dasar 8,85 $\%$ serta sebagian kecil yang menamatkan pendidikannya pada jenjang Diploma yaitu 0,90 $\%$ dan Sarjana (S1) 1,25\%. Dari jumlah penduduk Desa Jongkong Kiri Hilir yang berjumlah 881 jiwa, masih ada yang tidak tamat pendididikan Sekolah Dasar yaitu berjumlah 131 jiwa atau $14,87 \%$. Penduduk Desa Jongkong Kiri Hilir jika dilihat dari profesi atau mata pencarian adalah menukini berbagai profesi. Sebagian besar penduduk di Desa Jongkong Kiri Hilir berprofesi atau bekerja sebagai petani dan nelayan, penduduk yang berprofesi sebagai petani berjumlah 348 jiwa, sedangkan yang berprofesi sebagai nelayan berjumlah 157 jiwa, hal ini dikarenakan wilayah Desa Jongkong Kiri Hilir yang sebagian besar berupa lahan perkebunanan, lahan pertanian dan danau.
Kehidupan Masayarakat Desa Jongkong Kiri Hilir dapat dikatakan cukup pluralistik hidup rukun, ini terbukti dari terbinanya hubungan yang harmonis antar pemeluk agama. Agama yang dipeluk penduduk di Desa Jongkong Kiri Hilir yaitu agama Islam dan Khatolik. Sebagian besar penduduk Desa Jongkong Kiri Hilir menganut agama Islam yaitu 92,74 \%, dan sebagian kecil menganut agama Khatolik yaitu 7,26\%. Kebijakan E-KTP merupakan bagian dari program pemerintah yang dikenal sebagai E-Government. Program EGovernment yang diterapkan oleh pemerintah bertujuan untuk mewujudkan pemerintahan yang demokratis, transparan, bersih, adil, akuntabel, bertanggungjawab, responsif, efektif dan efisien.

\section{Sosialisasi Kebijakan}

Sebagai suatu kebijakan, program E-KTP dilakukan dengan berbagai tahapan. Tahapan yang pertama sebelum pelaksanaan E-KTP adalah tahapan sosialisasi program E-KTP. Bedasarkan hasil wawancara dengan Kepala Desa Jongkong Kiri Hilir, diperoleh informasi bahwa: program E-KTP di Desanya telah dilakukan sosialisasi kebijakan, pelaksanaan sosialisasi program E-KTP dilaksanakan oleh Pihak Dinas Catan Sipil dan Kependudukan Kabupaten Kapuas Hulu dan Aparatur Pemerintah Kecamatan Jongkong. Menurut Kepala Desa, sosialisasi kebijakan E-KTP yang dilakukan oleh Pihak Dinas Catan Sipil dan Kependudukan Kabupaten Kapuas Hulu Aparatur Kecamatan Jongkong dilakukan secara tidak terjadual, dimana sosialisasi dilakukan berupa pemberitahuan secara lisan baik kepada Aparatur Pemerintahan Desa Jongkong Kiri Hilir maupun kepada Masyarakat.

Berkaitan dengan sosialisasi Program E-KTP tersebut, kegiatan sosialisasi program E-KTP yang dilakukan di Desa Jongkong Kiri Hilir dilakukan oleh Pemerintah Desa Jongkong Kiri Hilir kepada masyarakat dengan cara pemebitahuan secara lisan yang disampaikan dalam rapat di Kantor Kepala Desa dan diumumkan secara lisan pada saat sholat Jumat di masjid yang terdapat di Desa Jongkong Kiri Hilir. Sejalan dengan hala tersebut, hasil wawancara dengan Para Kepala Urusan (KAUR) Desa Jongkong Kiri Hilir mengatakan, sosialisasi program E-KTP yang dilaksanakan di Desa Jongkong Kiri Hilir juga disampaikan oleh Kepala Desa dan Sekretaris Desa dalam kegiatan Musyawarah Pemebangunan Desa (Musrenbangdes) dan pemebtitahuan secara tertulis berupa pengumuman atau hibauan kepada masyarakat yang diumumkan di papan pengumuman atau papan informasi yang terdapat di Kantor Kepala Desa Jongkong Kiri Hilir.

Sosialisasi program E-KTP yang dilaksanakan di Desa Jongkong Kiri Hilir dilakukan secara tidak terjadual dimana kegiatan sosialisasi 
Kebijakan E-KTP yang dikeluarkan oleh pemerintah tersebut, disampaikan oleh Aparatur Desa Jongkong Kiri Hilir kepada masyarakat tidak dengan jadual khusus, melainkan ditumpangkan dalam berbagai kegiatan Pemerintah Desa seperti: acara rapat umum dengan masyarakat, kegiatan Musrenbangdes dan kegiatan-kegiatan lainnya. Tujuan sosialisasi Program E-KTP menurut Kepala Desa Jongkong Kiri adalah untuk memberikan informasi kepada masyarakat tentang manfaatnya E-KTP pada masa-masa yang akan datang. dalam hal proses pelayananya pemerintah, baik pada tingkat Desa, kecamatan maupun pada tataran pemerintahan yang lebih tinggi, serta disisi E-KTP merupakan dokumen identitas bukti diri resmi penduduk yang diterbitkan oleh Dinas Kependudukan dan Pencatatan Sipil (Disduk Capil) dan berlaku di seluruh wilayah Negara Kesatuan Republik Indonesia (NKRI). Selain sebagai dokumen identitas diri, KTP juga sangat diperlukan untuk registrasi ke beberapa tempat resmi yang membutuhkan identitas asli setempat.

\section{Pelaksanaan Kebijakan}

Implementasi kebijakan merupakan aspek penting dari keseluruhan proses kebijakan, karena apabila suatu kebijakan tidak diimplementasikan, maka akan menjadi sekedar impian belaka.Dalam pelaksaan proram E-KTP di Desa Jongkong Kiri Hilir, Kepala Desa Jongkong Kiri Hilir mengatakan : Proram E-KTP dilaksanakan dengan berpedoman kepada peraturan perundang-undangan yang berlaku. Selanjutnya Kepala Desa Jongkong Kiri Hilir menjelaskan dalam pelaksanaan pembuatan E-KTP, pihak pemerintahan Desa Jongkong Kiri hanya sebatas memfasilitasi masyarakat yang akan mengurus E-KTP di kantor Camat Jongkong .

Proses fasilitasi pembuatan E-KTP yang dilakukan di tingkat Pemerintahan Desa Jongkong Kiri Hilir meliputi pengeluaran surat ketarangan atau pengantar Desa dan penyedian anggaran biaya bantuan konsumsi dan transfortasi bagi penduduk yang berasal dari dusun terpencil.nBerkaitan dengan bantuan dana konsumsi dan transfortasi, hasil wawancara dengan kepala Desa Jongkong Kiri Hilir mengatakan, angaran bantuan tersebut merupakan hasil inisiatif pemerintahan Desa yang di ambil dari dana kas desa, hal ini dilakukan mengingat tidak ada dana atau anggaran khusus yang diperuntukan untuk membantu masyarakat terpencil dalam pengurusan E-KTP di Kecamatan jongkong. Sejalan dengan hal tersebut, menurut Ketua BPD desa Jongkong Kiri Hilir, kebijakan bantuan dana transfortasi dan konsumsi yang diberikan oleh Pemerintah Desa Jongkong Kiri Hilir adalah merupakan hasil kesepatan bersama antara BPD dan Pemerintah Desa Jongkong Kiri Hilir, bantuan tersebut diberikan kepada masyarakat terpencil yang terdapat di Desa Jongkong Kiri Hilir dengan harapan dapat mengurangi biaya transportasi masyarakat tersebut dalam pengurusan E-KTP.
Selanjutnya berkaitan dengan tata cara pengurusan E-KTP di tingkat Desa, tata cara pengurusan E-KTP di tingkat Desa Jongkong Kiri Hilir meliputi tahapan sebagai berikut :1).Pemohon (penduduk) meminta Surat Pengantar dari RT/RW kemudian menyampaikan Surat Pengantar ke Desa dengan melampirkan persyaratan yang dibutuhkan; 2).Pemohon mengisi formulir permohonan KTP, setelah itu petugas di Desa menerima dan meneliti kelengkapan berkas persyaratan; 3).Petugas di Desa mencatatnya dalam Buku Harian Peristiwa Penting dan Kependudukan (BHPPK) dan Buku Induk Penduduk (BIP); 4).Kepala Desa menandatangani formulir permohonan KTP, selanjutnya 5).Pemohon atau petugas Desa menyerahkan formulir yang telah diisi dan dilampiri persyaratan ke Kecamatan.

Pengurusan E-KTP dapat dilakukan penduduk baik secara massal maupun secara reguler.Ketentuan tersebut tertuang di dalam Peraturan Menteri Dalam Negeri Nomor 9 Tahun 2011 pasal 2 ayat 2 yang berbunyi : Penerbitan KTP Elektronik meliputi : penerbitan KTP Elektronik secara massal; penerbitan KTP Elektronik secara reguler; dan penerbitan KTP Elektronik bagi Penduduk yang tidak mampu datang/melapor ke tempat pelayanan KTP Elektronik.

Dalam pembuatan E-KTP tentunya memerlukan persyaratan. Persyaratan pengurusan E-KTP berpedoman Kepada Permendagri Nomor 9 Tahun 2011, yaitu meliputi : 1).Telah berusia 17 tahun atau sudah kawin atau pernah kawin; 2).Surat Pengantar RT/RW dan Kepala Desa/Lurah; 3).Fotokopi KK; 4).Fotokopi Akta Nikah/Akta Kawin bagi penduduk yang belum berusia 17 tahun; 5).Fotokopi Akta Kelahiran; 6).Surat Keterangan Pindah yang diterbitkan oleh pemerintah Kabupaten/Kota dari daerah asal, bagi penduduk pendatang dari luar Kabupaten/Kota; 7).Surat Keterangan Datang dari Luar Negeri yang diterbitkan oleh Instansi Pelaksana bagi WNI yang datang dari Luar Negeri karena pindah; 7).Datang langsung untuk di foto (E-KTP) atau melampirkan pas foto terbaru ukuran $3 \times 4$ sebanyak 2 lembar (KTP Lama).

Berkaitan dengan persyaratan pengurusan EKTP pada tingkat Desa, warga atau masyarakat tidak mengalami kendala dalam pengurusan persyaratanatan, hal ini dikarenakan Kepala Desa hanya sebatas mengeluarkan Surat Pengantar Desa, dimana dalam penerbitan surat pengantar Desa, warga yang hanya diminata menunjukan Kartu Keluarga dan surat Pengantar dari Ketua RT setempat, sedangakan persyaratan yang lainnya dilengkapi oleh warga tersebut dalam pengurusan E-KTP di tingkat Kecamatan.

Berdasarkan Permendagri Nomor 9 tahun 2018, Tata cara penerbitan KTP Elektronik secara reguler bagi Penduduk WNI: Penduduk melapor 
kepada petugas di tempat pelayanan KTP Elektronik, dengan mengisi formulir permohonan dan membawa persyaratan berupa:

Nomor Induk Kependudukan Nasional; Fotokopi Kartu Keluarga; dan Surat pindah dan KTP Elektronik bagi Penduduk yang pindah atau KTP Elektronik yang rusak bagi Penduduk yang KTP nya rusak atau Surat keterangan kehilangan dari Kepolisian bagi Penduduk yang KTP nya hilang. Petugas di tempat pelayanan KTP Elektronik merekam isi formulir permohonan KTP Elektronik ke dalam database kependudukan; Petugas sebagaimana dimaksud pada huruf b melakukan verifikasi data penduduk secara langsung; Petugas operator melakukan pengambilan dan perekaman pas photo, tanda tangan, dan sidik jari penduduk; Petugas sebagaimana dimaksud pada huruf $b$ membubuhkan tanda tangan dan stempel tempat pelayanan KTP Elektronik pada Formulir Permohonan sebagaimana dimaksud pada huruf a; Formulir permohonan sebagaimana dimaksud pada huruf e sebagai bukti telah dilakukan verifikasi, pengambilan dan perekaman pas photo, tanda tangan dan sidik jari penduduk sebagaimana dimaksud pada huruf $\mathrm{c}$ dan huruf $\mathrm{d}$; Petugas operator melakukan penyimpanan data sebagaimana dimaksud pada huruf $\mathrm{d}$ dan biodata penduduk ke dalam database di tempat pelayanan KTP Elektronik; Data yang disimpan dalam database sebagaimana dimaksud pada huruf g dikirim melalui jaringan komunikasi data ke server Automated Fingerprint Identification System di pusat data Kementerian Dalam Negeri; Data penduduk sebagaimana dimaksud pada huruf h disimpan dan dilakukan proses identifikasi ketunggalan jatidiri seseorang; Hasil identifikasi sidik jari penduduk sebagaimana dimaksud pada huruf i, apabila : identitas tunggal, data dikembalikan ke tempat pelayanan KTP Elektronik; identitas ganda, dilakukan klarifikasi dengan tempat pelayanan KTP Elektronik. Dinas Kependudukan dan Pencatatan Sipil Kabupaten/Kota melakukan personalisasi data yang sudah diidentifikasi sebagaimana dimaksud pada huruf j angka 1 ke dalam blangko KTP Elektronik; Setelah dilakukan personalisasi sebagaimana dimaksud pada huruf k, Dinas Kependudukan dan Pencatatan Sipil Kabupaten/ Kota mendistribusikan KTP Elektronik ke tempat pelayanan KTP Elektronik; Hasil verifikasi sidik jari penduduk sebagaimana dimaksud pada huruf k: apabila datanya sama, maka KTP Elektronik diberikan kepada penduduk; apabila datanya tidak sama, maka KTP Elektronik tidak diberikan kepada penduduk. n. Dalam hal datanya tidak sama sebagaimana dimaksud pada huruf n angka 2, Petugas di tempat pelayanan KTP Elektronik mengembalikan KTP Elektronik ke Kementerian Dalam Negeri melalui Dinas Kependudukan dan Pencatatan Sipil Kabupaten/Kota untuk dimusnahkan.
Pada tataran implementasi kebijakan E-KTP di tingkat Desa Jongkong Kiri Hilir, jika mengacu kepada pendapat para ahli dapat dikatakan aparatur Desa Jongkong Kiri Hilir telah berupaya untuk mensukseskan program E-KTP di mana sebagai bagian dari aparatur pelaksana program E-KTP, Pemerintah Desa Jongkong Kiri Hilir telah melakukan ikhtiar-ikhtiar untuk mencapai suksesnya program atau Kebijakan E-KTP yang telah ditetapkan oleh Pemerintah, dan sejalan dengan pemikiran Winarno (2002:102) mengatakan implementasi kebijakan merupakan alat administrasi hukum dimana berbagai aktor, organisasi, prosedur dan teknik yang bekerja bersama-sama untuk menjalankan kebijakan guna meraih tujuan yang diinginkan serta pendapat Wibawa (1992:15) tujuan implementasi kebijakan adalah untuk menetapkan arah agar tujuan-tujuan kebijakan publik dapat direalisasikan sebagai hasil dari kegiatan pemerintah.

\section{Faktor Pendukung dan Penghambat}

Faktor pendukung implementasi kebijakan E-KTP yang dilaksanakan di Desa Jongkong Kiri Hilir, menurut Kepala Desa Jongkong Kiri Hilir adalah, pertama, kesadaran masyarakat yaitu masyarakat yang terdapat di Desa Jongkong Kiri Hilir mendukung program E-KTP yang dikeluarakan pemerintah, dan kedua,kesiapan aparatur Desa Jongkong Kiri Hilir yang yang partisipatif dan koordinatif dalam melaksanakan tugas-tugas pemerintahan desa. Sejalan dengan Kepala Desa, hasil wawancara dengan Ketua BPD Desa Jongkong Kiri Hilir mengatakan, faktor kesigapan dan tanggunggung jawab aparatur Desa dalam melaksanakan tugas-tugasnya terutama dalam pelaksanaan pengurusan persyaratan E-KTP menjadi faktor yang mendukung, dimana berdasarkan pengamatan BPD belum ada keluhan atau kritikan dari masyarakat berkaitan dengan pengurusan persyaratan E-KTP di tingkat Desa Jongkong Kiri Hilir. Aparatur desa selalu siap sedia melayani masyarakat dalam pengurusan persyaratana E-KTP, sebagai salah satu contoh masyarakat yang mengurusi persyaratan E-KTP selalu dilayani tepat waktu,hal ini dikarenakan Kepala Desa atau Sekretaris Desa selalu berada di Kantor Desa pada saat jam dan hari kerja, sehingga surat pengantar dari Desa dapat dikeluarkan pada hari pengurusan persyaratan E-KTP yang diminta oleh masyarakat.

Dalam hal penyelenggaraan tertib administrasi, pegawai secara administrasi dan teknisnya semestinya mempunyai kemampuan baik secara pengetahuan maupun keterampilannya terutama bagaimana menentukan isi surat dan mengamankan informasinya. Sumber daya aparatur merupakan asas utama dalam suatu organisasi yang menjadi perencana dan pelaku aktif dari setiap aktifitas organisasi, setiap orang akan berupaya 
menbangun, mendayagunakan semua sumber organisasinya secara optimal dalam rangka mencapai tujuannya. Sebagai salah satu sumber daya organisasi yang sangat penting, maka sumber daya aparatur pemerintah desa perlu diperhatikan atau dirancang sedemikian rupa agar dapat memenuhi harapan sebuah organisasi. Jika dilihat dari segi jumlahnya, Aparatur Pemerintahan Desa yang terdapat di Kantor Kepala Desa Jongkong Kiri Hilir dapat dikatakan sudah memenuhi kebutuhan organisasi pemerintahan desa sesuai ketentuan peraturan perundang-undangan yang berlaku. Ditinjau dari segi jumlah dan tingkat pendidikan Aparatur Pemerintah Desa Jongkong Kiri Hilir, sudah dapat dikatakan sudah memadai dan sesuai dengan ketentuan peraturana perundangundangan yang berlaku, yaitu seluruh struktur organisasi pemerintahan Desa terdapat aparatur desa dan rata-rata Aparatur Pemerintah Desa Jongkong Kiri Hilir berpendidikan pada jenjang SLTA. Berdasarkan pengamatan penulis di lapangan, ketersediaan sumber daya manusia BPD Desa Jongkong Kiri Hilir juga sudah memadai, dimana semua anggota BPD Desa Jongkong Kiri Hilir sudah berpendidikan pada jenjang SLTA.

Faktor pedukung implementasi kebijakan E-KTP di Desa Jongkong Kiri Hilir adalah ketersediaan sarana dan prasaran yang terdapat di Kantor Kepala Desa Jongkong Kiri Hilir, hal ini sesuai dengan hasil wawancara dengan Kepala Desa Jongkong Kiri Hilir yang mengatakan dalam pekayanaan pengurusan E-KTP di Desanya ketersediaan sarana dan parasarana Desa Jongkong Kiri Hilir adalah merupakan faktor pendukung. Demikian juga hasil wawancara dengan Ketua BPD Desa Jongkong Kiri Hilir yang mengatakan fasilitas tyang terdapat di Kantor Desa Jongkong Kiri Hilir merupakan penunjang bagi Aparatur Desa Jongkong Kiri Hilir dalam memberikan pelayanan E-KTP kepada masyarakat. Begitu juga hasil wawancara dengan Kasi Kesra dan Pelayanan Desa Jongkong Kiri Hilir mengatakan bahwa pihaknya dalam hal ini bagian pelayanan sangat terbantu dengan fasilitas kerja yang terdapat di Kantor Kepala Desa Jongkong Kiri Hilir. Sarana dan prasarana yang terdapat di Kantor Kepala Desa Jongkong Kiri Hilir ketersedian sarana dan prasarana yang terdapat di Kantor Kepala Desa Jongkong Kiri Hilir dapat dikatakan sudah memadai dalam pelayanan pengurusan E-KTP di Tingkat Desa.

Dalam implementasi kebijakan E-KTP di Desa Jongkong Kiri Hilir disamping faktor pendukung, masih tedapat faktor penghambat. Dalam pelayanan E-KTP di Desa Jongkong Kiri Hilir masih menemukan kendala sehingga samapai dengan tahun 2018, masih terdapat warga masyarakat yang belum memiliki E-KTP. Masih terdapat warga masyarakat yang belum memiliki E-KTP dikarenakan oleh kendala geografis, dimana warga masyarakat yang berada di Dusun Kenasau kesulitan dalam melakukan pengurusan E-KTP dikarenakan letak dusun tersebut berada pada wilayah terpencil yang jaraknya dari ibu kota Desa dan Kecamatan dengan sarana transportasi yang dapat digunakan hanya melalui jalur sungai. Jarak tempuh melalui jalur sungai dari Kantor Kepala Desa Jongkong Kiri Hilir dengan Dusun Kenasau jika menggunakan speed 15 HP mencapai 4 jam, jka menggunakan speed 3.2 HP mencapai 10 jam dan jika menggunakan sampan (berdayung) lebih dari 24 jam. Dengan Jarak yang jauh tersebut menyebabkan warga masyarakat kesulitan dalam pengurusan E-KTP di Kecamatan Jongkong. Selanjutnya Kasi Kesra dan Pelayanan Desa Jongkong Kiri Hilir mengatakan, warga masyarakat yang belum mengurus E-KTP yang terdapat di Dusun Kenasau pada umumnya termasuk warga yang kurang mampu, mereka bekerja sebagai nelayan tradisional. jumlah penduduk Desa Jongkong Kiri Hilir sampai dengan tahun 2017 berjumlah 881 jiwa yang terdiri dari 455 jiwa berjenis kelamin laki-laki dan 426 jiwa berjenis kelamin perempuan. Dari Jumlah penduduk 881 jiwa tersebut yang wajib memiliki Kartu Tanda Penduduk Elektronik seharusnya berjumlah 724 orang, namun yang dalam kenyatannya penduduk yang sudah memiliki KTP-E baru berjumlah 677 orang, sehingga masih terdapat penduduk yang belum memiliki KTP-E berjumlah 47 orang. Kenyataan lainnya juga terjadi pada pembuatan Kartu Keluarga (KK), dimana berdasrkan data yang terdapat di Kantor Kepala Desa Desa Jongkong Kiri Hilir, penduduk yang wajib memiliki KK seharusnya berjumlah 293 orang, namun dalam kenyataannya, penduduk yang sudah memiliki KK baru berjumlah 279 orang, sehingga masih terdapat penduduk yang belum memiliki KK sebanyak 14 orang.

\section{KESIMPULAN DAN SARAN}

Sosilisasi Kebijakan Kartu Tanda Penduduk (E-KTP) Di Desa Jongkong Kiri Hilir dilakukan secara tidak terstruktur dan terjadwal. yang melaksanakan Sosilisasi kebijakan E-KTP Di Desa Jongkong Kiri Hilir adalah Pihak Dinas Catatan Sipil dan Kependudukan Kabupaten Kapuas Hulu, Pemerintah Kecamatan Jongkong dan Pemerintahan Desa Jongkong Kiri Hilir. Bentuk sosialisasi adalah secara lisan yang disampaikan dalam rapat atau pertemuan di Desa dan pemberitahuan di tempat ibadah pada hari jumat.Dalam pelaksanaan kebijakan E-KTP di Desa Jongkong Kiri Hilir, Aparatur Desa Jongkong Kiri Hilir berpedoman pada peraturan perundangundangan yang berlaku dan keterlibatan pemerintahan Desa hanya sebatas memfasilitasi dan membuat surat pengantar bagi warga Desa yang akan melakukan proses perekaman dan pembuatan E-KTP di tingkat Kecamatan Jongkong. 
Dalam pelaksanaan kebijakan E-KTP di Desa Jongkong Kiri Hilir, terdapat faktor pendukung dan faktor penghambat. Faktor pendukung berupa ketersediaan sumber daya manusia Apartur Desa Jongkong Kiri Hilir yang sesuai dengan struktur organisasi dan ketersediaan sarana dan prasarana yang memadai dalam proses pengurusan E-KTP pada tingkat Desa. Sedangkan faktor penghambat dalam pelaksanaan kebijakan E-KTP di Desa Jongkong Kiri Hilir adalah faktor geografis, dimana warga masyarakat yang terdapat di wilayah terpencil kesulitan dalam pengurusan E-KTP baik di tingkat desa maupun di tingkat Kecamatan.

Disarankan kepada Pemerintah Daerah Kabupaten Kapuas Hulu khususnya Dinas Catatan Sipil dan Kependudukan dan Pemerintah Kecamatan Jongkong, dalam sosialisasi kebijakan pemerintah khususnya di bidang kependudukan dapat dilakukan secara terstruktur dan terjadual, sehingga pelaksanaan sosialisasi kebijakan dibidang kependudukan dapat berjalan secara efektif dan efesien. Peran serta atau keterlibatan Pemerintahan Desa tidak hanya sebatas mamfasilitasi saja melainkan lebih diberdayagunakan lagi yaitu proses perekaman data penduduk dalam pembuatan EKTP dapat di lakukan di tingkat Desa, sehingga mempermudah warga masyarakat dalam pengurusan E-KTP. Dalam rangka efektivitas pelaksanaan E-KTP di tingkat Desa khususnya di Desa Jongkong Kiri Hilir, sebaiknya Pemerintah Kecamatan Jongkong dapat mengambil kebijakan teknis, sehingga warga masyarakat yang kurang mampu dan berada diwilayah terpencil dapat dilayani dalam perekaman atau pembuatan E-KTP.

\section{DAFTAR PUSTAKA}

Ambarriani, S.A. 2000. Manajemen Biaya. Jakarta : Salemba Empat.

Anthony, R.N. et all. 1993. Sistem Pengendalian Manajemen. Terjemahan Agus Maulana. Edisi Kelima. Jakarta : Erlangga. 1998, dan Vijay Govindarajan. 1998. Management Control System. Ninth Edition. Mc Grow Hill : Illionis. Inc.

Dunn, W.N.1988. Analisa Kebijakan Publik. (Terjemahan) oleh Muhajir Darwin, Yogyakarta: Hanindita Offset.

Effendy, O.U.1992. Ilmu, Teori \& Filsafat Komunikasi. Bandung: Citra Aditya Bakti
Islamy, I.M. 2000. Prinsip-Prinsip Perumusan Kebijakan Negara. Jakarta : Bumi Aksara.

Manullang, M. 1983. Dasar-Dasar Manajemen. Jakarta : Ghalia Indonesia.

Narbuko \& Achmadi. 1997. Metodologi Penelitian. Jakarta : Bumi Aksara

Soekamto, S, 2009. Sosiologi Suatu Pengantar. Jakarta: Grafindo

Sunggono, B. 1994. Hukum dan Kebijakan Publik.Jakarta: Sinar Grafika

Suryabrata, S. 2005. Metodologi Penelitian. Jakarta: PT. Raja Grafindo Persada.

Supriyono. 1995. Akuntansi Manajemen. Edisi Pertama. Yogyakarta: STIE YKPN.

Tangkilisan. H.N, 2003. Implementasi Kebijakan Publik, Transformasi Pikiran George Edwards, Yogyakarta: Lukan Ofset. (IKAPI).

Wibawa, S. 19992. Laporan Penelitian Studi Implementasi Kebijakan Jurusan Ilmu Administrasi Negara. Fisipol. Yogyakarta : UGM.

Winarno, B. 2005. Teori dan Proses Kebijakan Publik. Yogyakarta : Media Presindo.

Peraturan Perundang-Undangan:

Negara Republik Indonesia, 2006. Undang-Undang Nomor 23 Tahun 2006 Tentang Administrasi Kependudukan. Tidak Diterbitkan

Negara Republik Indonesia, 2009. Peraturan Presiden Nomor 26 Tahun 2009 Tentang penerapan KTP berbasis Nomor Induk Kependudukan secara nasional. Tidak Diterbitkan

Negara Republik Indonesia, 2010. Peraturan Presiden No. 35 Tahun 2010 tentang perubahan Peraturan Presiden No. 26 Tahun 2009 Persiapan dan pelaksanaan Pemutakhiran Data Kependudukan dan Pencatatan Sipil. Tidak Diterbitkan

Negara Republik Indonesia, 2003. Instruksi Presiden Nomor 3 tahun 2003 tentangPelaksanaan dan Strategi Nasional Pengembangan Egovernment Republik Indonesia. Tidak Diterbitkan

Negara Republik Indonesia. 2005, Peraturan Menteri Dalam Negeri Nomor 39 Tahun 2005 Tentang Tata Kearsipan Di Daerah.Tidak Diterbitkan 